\title{
Achievements in management and utilization of southern grasslands
}

\author{
CARL S. HOVELAND
}

Hoveland is Terrell distinguished professor in the Department of Crop \& Soil Sciences at the University of Georgia, Athens, Georgia 30602.

\begin{abstract}
Grasslands in the humid southern USA are utilized primarily for grazing on improved pastures, most of which were developed since the 1930s and 1940s. Virtually all of these grasslands were developed from species introduced from other areas of the world. Major achievements in successfully developing these grasslands, often on eroded cropland, were: (a) introduction of Kentucky 31 tall fescue (Festuca arundinacea Schreb.); (b) introduction of Pensacola bahiagrass (Paspalum notatum Flugge); (c) breeding of Coastal bermudagrass [Cynodon dactylon (L.) Pers.]; (d) fertilizer and lime use along with availability of low-cost N; (e) no-till planting of winter annual grasses; (f) pasture renovation with legumes; (g) herbicides for weed control; (h) recycling of agricultural wastes in forage production; (i) development of round hay baler; (j) controlled grazing; ( $k$ ) discovery of the tall fescue fungal endophyte and its effect on livestock and the grass plant; (l) development of grazing-tolerant alfalfa; $(m)$ improved cool season annual grasses and legumes for winter grazing; and (n) near infrared reflectance spectroscopy for rapid and low-cost forage analysis. Future areas of emphasis in improvement of these grasslands may include: (a) greater use of grazing-tolerant grasses and legumes; (b) stress-tolerant tall fescue with "friendly" non-toxic endophytes; (c) feed antidotes to the toxins of endophyte-infected tall fescue; (d) use of herbicide-and pest-resistant biotechnology genes in forage plants; (e) use of gypsum to alleviate subsoil acidity and improve rooting depth of aluminum-sensitive forage cultivars; (f) greater use of computers in information access and decision making by livestock producers; (g) greater use of forages for wildlife food; (h) breeding of pasture plants with greater winter productivity; (i) development of a perennial grass biomass energy industry for electrical generation and liquid fuel production.
\end{abstract}

Key Words: forage achievements, southern USA, grazing, future forage emphasis

The southern USA from eastern Texas and Oklahoma to Virginia and Georgia on the Atlantic coast is a humid region with annual rainfall ranging from $1,000 \mathrm{~mm}$ to over $1,600 \mathrm{~mm}$ (Ball et al. 1996). The native vegetation was mainly deciduous and coniferous forest. Much of this land was cleared and continuously cropped with cotton (Gossypium hirsutum L.) and other row crops for over a century, often resulting in severe soil erosion. Soils throughout much of the region tend to be acid and low in nutrients. Acid subsoils which cause aluminum or manganese

Manuscript accepted 29 Aug. 1999.

\section{Resumen}

Los pastizales de la región húmeda del sudeste de E.U.A. son utilizados principalmente para el apacentamiento en pastizales mejorados, la mayoría de los cuales se desarrollaron desde las décadas de 1930 y 1940. Virtualmente todos estos pastizales se son de especies introducidas de otras áreas del mundo. Los mayores logros que contribuyeron al establecimiento exitoso de estos pastizales, los cuales a menudo se establecieron en áreas de cultivo erosionadas, fueron: (a) la introducción del "Kentucky 31 tall fesuce" (Festuca arundinacea Schreb.); (b) la introducción del "Pensacola bahiagrass" ( Paspalum notatum Flugge); (c) el mejoramiento del "Costal Bermuda" (Cynodon Dactylon (L.) Pers.); (d) El uso de fertilizantes y cal junto con la disponibilidad de nitrógeno a bajo costo; (e) la siembra de zacates anuales invernales en sistemas de cero labranza; (f) la renovación de praderas con leguminosas; (g) el uso de herbicidas para el control de maleza; (h) el reciclaje de subproductos agrícolas en la producción de forraje; (i) el desarrollo de la empacadora de pacas redondas; (j) el apacentamiento controlado; (k) el descubrimiento del hongo endófito del "Tall fescue" y sus efectos en el ganado y la planta; (l) el desarrollo de alfalfa tolerante al apacentamiento; (m) el uso de especies mejoradas de zacates y leguminosas de estación fría para el apacentamiento en invierno y (n) el uso de la espectroscopia de reflectancia infrarroja para análisis rápidos de forraje a bajo costo. Las áreas a enfatizar en el futuro para mejorar estos pastizales pueden incluir: (a) un mayor uso de zacates y leguminosas tolerantes al apacentamiento; (b) el uso de "Tall fescue" tolerante al estrés con hongos endófitos no tóxicos; (c) el uso antídotos alimenticios para las toxinas producidas por el "Tall fescue" infectado por hongos endófitos; (d) el uso de biotecnología para la inclusión de genes que le confieran a las plantas forrajeras resistencia a herbicidas y plagas; (e) el uso de yeso para disminuir la acidez del subsuelo y mejorar la profundidad de enraizamiento de cultivares forrajeros sensitivos al aluminio; (f) un mayor uso de computadoras como herramienta de los ganaderos para el acceso información y tomar decisiones; (g) un mayor uso de forrajes como alimento para la fauna silvestre; (h) el mejoramiento de plantas de pastizal con una mayor productividad en invierno; (i ) el desarrollo de una biomasa de zacates perennes para la generación de energía eléctrica y combustibles líquidos.

toxicity are a problem in subtropical clay and sandy soils of the lower South. Water-holding capacity of many soils in this region is low and this is compounded by acid subsoils which often results in shallow plant root development. Thus, droughts can be a problem in this relatively high rainfall region, a major factor in the shift from crop production to forestry or improved grasslands. 
Southern grasslands are overwhelmingly utilized for grazing rather than for harvested and stored forage as is common in many other areas of the USA. There are about 24 million hectares of pasture in the South which is $75 \%$ of the total pastureland in humid regions of the USA (Hoveland 1992). In the upper South states of Kentucky, Tennessee, Virginia, and much of North Carolina, tall fescue (Festuca arundinacea Schreb.) is the dominant grass, with lesser amounts of orchardgrass (Dactylis glomerata L.), Kentucky bluegrass (Poa pratensis L.), and timothy (Phleum pratense L.). Tall fescue is dominant in northern parts of Arkansas, Mississippi, Alabama, Georgia, and South Carolina. In the lower South, from eastern Oklahoma and Texas to the Atlantic Ocean, the major grasses are bermudagrass [Cynodon dactylon (L.) Pers.], bahiagrass (Paspalum notatum Flugge), dallisgrass (Paspalum dilatatum Poir.), rye (Secale cereale L.), wheat (Triticum aestivum L.), annual ryegrass (Lolium multiflorum Lam.), and smaller amounts of tall fescue. Major legumes in the upper South include white clover (Trifolium repens L.), red clover ( $T$. pratense $\mathrm{L}$.), and alfalfa (Medicago sativa L.). Although legumes are less important in the lower South because of greater environmental stress, they include white clover, red clover, sericea lespedeza [Lespedeza cuneata (Dum-Cours) G. Don], alfalfa, Korean lespedeza (Lespedeza stipulacea Maxim.), perennial peanut (Aarachis glabrata Benth.), and the winter annual clovers, arrowleaf ( $T$. vesiculosum Savi), crimson (T. incarna tum L.), berseem ( $T$. alexandrinum L.), and rose (T. hirtum All.).

Southern grasslands are mainly used for beef cow-calf production, this region having nearly one-half of USA beef cows (Anon. 1998). Grazing of weaned beef calves on high-quality pastures to feeder weight is another important enterprise. Dairying, mainly in the upper South, utilizes a considerable amount of grassland. Pleasure horses continue to increase in number and utilize substantial areas of pasture as well as hay. Goat and deer farming for meat production on pasture are also increasing.

\section{Achievements in Management and Utilization}

Although the South was primarily a forested landscape, on favorable sites with better soils there were native warm season bunchgrasses such as big bluestem (Andropogon geraardii Vitman), indiangrass [Sorghastrum nutans (L.) Nash], switchgrass (Panicum virgatum L.), and eastern gamagrass [Tripsacum dactyloides (L.) L.]. These grasses were soon overgrazed by cattle of early settlers and replaced by less palatable poor quality species such as broomsedge (Andropogon virginicus L.) (Ball et al. 1996). Thus, when animal agriculture replaced much of the row cropping on eroded, acid, low fertility soils during the 1930 s to1950s it was based on introduced forage species from other areas of the world. The transformation of the Southern landscape to planted grasslands in a humid environment was dependent on research and extension achievements since the 1930s. Some of the most significant of these achievements are reviewed here.

\section{Introduction of Kentucky 31 tall fescue}

Cool season grasses such as orchardgrass, timothy, and Kentucky bluegrass had been reasonably successful on favorable sites in the upper South but on droughty soils and in the lower South they did not persist. Thus, over much of the Southern region there was no adapted cool season perennial grass to provide grazing during the long winter dormancy season of warm season perennial grasses. The release of 'Kentucky 31' tall fescue in 1943 by E.N. Fergus (1952) at the University of Kentucky is without doubt the single greatest achievement in the development of Southern grasslands. The rapid acceptance and planting of Kentucky 31 tall fescue covered pastureland and roadsides over much of the South, making it difficult today to visualize the landscape without this grass which has contributed so much to livestock production and soil conservation. Tall fescue is the most widely grown grass in the humid area of the USA, covering over 14 million ha, most of which is the Kentucky 31 cultivar (Buckner et al. 1979). The reasons for its acceptance are probably the features originally listed by Fergus (1952): dependability, adaptability to a wide range of soils, affording grazing most of the year, and palatability to livestock, although the latter feature may be questioned in view of the toxic fungal endophyte problem.

\section{Breeding of Coastal bermudagrass}

Common bermudagrass was brought to Savannah, Georgia in 1751 and spread throughout the South where it became a valuable pasture plant (Burton and Hanna 1995). However, when Dr. Glenn Burton came to Tifton, Georgia in 1936 to begin a forage grass breeding program, common bermudagrass was a serious weed in cotton and corn crops. Thus, his choice of bermudagrass for the forage breeding program was not well received by local row crop farmers. 'Coastal' bermudagrass, released in 1943, was the first warm season perennial grass cultivar developed with modern breeding technology (Burton 1954). However, it had the handicap of requiring vegetative propagation so methodology had to be developed for dependable establishment. In spite of this, Coastal eventually became widely planted because of its superior characteristics: much higher yields than common bermudagrass, a longer productive season, greater disease resistance, deeper root development and more drought tolerance, and rapidity of hay drying. Coastal bermudagrass filled an important need in supplying dependable forage for livestock in the lower South, becoming the most important hay plant in the lower South, grown on about 2 million ha. Since then, additional improved cultivars have been developed by Dr. Burton with characteristics such as better cold hardiness, forage yield, and digestibility (Burton and Hanna 1995).

\section{Introduction of Pensacola bahiagrass}

Common bahiagrass, a relatively lowyielding grass with little winter hardiness, had been grown in the sandy Gulf Coastal Plain area since the early 1920s (Burson and Watson 1995). In 1935 an observant county agent, E. H. Finlayson, discovered a superior bahiagrass growing near the docks in Pensacola, Fla. which was increased as the 'Pensacola'cultivar (Finlayson 1941). This chance introduction, probably from southern Brazil, has been widely planted on sandy Coastal Plain soils and makes up most of the USA bahiagrass hectarage. This aggressive and competitive grass continues to be highly popular among beef cow-calf producers for dependable low-input pasture because of its tolerance to soil acidity and low fertility, drought, and close continuous grazing. More recently, the 'Tifton 9' cultivar with $40 \%$ higher yield was released by Burton (1989) and is having an important impact.

\section{Fertilizers, lime, and low-cost nitro- gen}

High analysis fertilizer and lime use has been a major factor in Southern grassland improvement, mainly because most soils in the region are acid and low in nutrients. Without these inputs, higher yielding forage cultivars would not have achieved 
their potential. Most of all, the availability of high-analysis synthetic $\mathrm{N}$ fertilizers at lower cost made it possible to produce dependable high yields from improved forages such as Coastal bermudagrass (Wilkinson and Langdale 1974). An unfortunate effect of low-cost $\mathrm{N}$ fertilizer has been to discourage the use of clovers and reduce the emphasis on development of adapted clovers and other legumes.

\section{No-till planting of winter annual grasses}

Winter dormancy of bermudagrass and bahiagrass in the Lower South offered an opportunity to grow $\mathrm{N}$-fertilized rye or wheat (Ball et al. 1996). However, unsatisfactory sod penetration by conventional grain drills limited this practice until development of sturdy no-till drills which greatly expanded winter and spring pasture.

\section{Pasture renovation with legumes}

Planting of alfalfa, red and white clovers into tall fescue pastures supplies $\mathrm{N}$ to the ecosystem, improves nutrient quality of grazing, and often increases length of the grazing season (Ball et al. 1996). This has allowed the establishment of legumes in the grass sod by cattle trampling or drilling without plowing, an important consideration on erodible land. Herbicides have been useful to kill or suppress tall fescue in no-till planting. No-till planting of legumes has been widely adopted in the upper South but it has been much less successful in the lower South because of greater environmental stress.

\section{Herbicides for weed control}

The advent of dependable herbicides has greatly aided forage establishment and reduced weeds in pasture and hay land, improving productivity and eliminating some livestock toxicity problems

\section{Use of agricultural wastes in forage production}

In intensive poultry producing areas, broiler and layer litter has been commonly utilized to improve productivity of pastures and hay land. Dairy and swine wastes are also important in some areas. Application of these wastes has been beneficial in reducing pasture fertilizer costs but they have also had adverse effects in eliminating legumes and accentuating the toxicity of endophyte-infected tall fescue.

\section{Development of round hay baler}

Haymaking was at one time a labor intensive operation when it was handled as a loose commodity. Mobile balers making rectangular small bales improved on this but were relatively slow. Machines that picked up hay from a windrow and rolled it into a large round bale required more power than balers making small rectangular bales but were a major achievement in reducing labor requirements and speeding up the operation to avoid rain damage at critical times (Rotz and Muhtar 1991). Unfortunately, this has been a mixed blessing as most of these large round bales are generally stored outside on the ground exposed to weather so losses of edible forage often approach $40 \%$ (Rotz and Muck 1994).

\section{Controlled grazing}

Uncontrolled grazing practices often result in substantial waste during periods of surplus growth, along with reduced forage quality and tiller development. The fundamental work of Mott (1960) established the effects of grazing pressure on gain per animal and gain/unit area in pasture. From this, practical methods of grazing management were devised to improve livestock productivity (Blaser et al. 1973). The development of improved polywire and polytape electric fences with low impedence chargers greatly reduced the cost of erecting cross fences on livestock farms. This made it possible to cheaply fence off areas to conserve unneeded pasture for hay and reduce waste. Further, it has allowed practical development of controlled grazing systems to improve pasture utilization and reduce waste.

\section{Discovery of the tall fescue fungal endophyte and its effect on livestock and the grass plant}

Although tall fescue flourished in stressful environments, it earned a reputation for poor animal performance. This stimulated a great deal of research effort for a number of years but no success in determining the cause of the toxicity problem until in 1976 USDA scientists at Athens, Ga. identified a fungal endophyte in tall fescue as the probable causal agent (Bacon et al. 1977). The endophyte toxicity relationship was conclusively shown in a 4-year Alabama grazing study (Hoveland et al. 1983). Since then, cultural management practices such as dilution with legumes or other grasses and feeding non-toxic hay have been utilized by many livestock producers to reduce toxicity problems. In spite of this, economic losses from reduced conception rates and weaning weights of beef cattle grazing tall fescue in the USA have been conservatively estimated at $\$ 609$ million annually (Hoveland 1993). Identifying the causal agent has allowed researchers to develop improved non-toxic endophyte-free cultivars that with good management can give excellent animal performance. Unfortunately, these endophyte-free cultivars are less tolerant than infected tall fescue of drought and overgrazing in summer than infected grass, often resulting in serious stand losses. The endophyte discovery stimulated research on endophyte-plant relationships, and the development of more persistent endophyte-free tall fescue cultivars.

\section{Development of grazing-tolerant alfalfa}

Alfalfa, the most productive long-season forage legume in the USA, was primarily harvested because successful grazing required very careful rotational stocking to maintain stands and vigor. The development of a truly grazing-tolerant alfalfa cultivar in Georgia made it possible to utilize this legume in pastures for dairy cattle, beef steers and heifers, and creep grazing of calves (Bouton et al. 1991). This development opened new opportunities for livestock producers, resulting in grazing-tolerant alfalfa being widely planted in the upper South and Midwest. Equally important, the technique pioneered by Bouton is now being used to enhance grazing tolerance in other forage species (Bouton et al. 1997).

\section{Improved cool season annual grasses and legumes for winter grazing}

Winter annual grasses and legumes are used in the lower South for high-quality pastures grazed by dairy cattle and weaned beef calves destined for western feedlots. Rye, wheat, and oats are widely grown with many dependable disease-resistant cultivars such as 'Wrens Abruzzi' rye developed by cereal breeders. 'Gulf' annual ryegrass had a major impact because it was the first cultivar with resistance to crown rust, a major problem in the Gulf Coast area (Weihing 1963). 'Marshall', a more recent annual ryegrass cultivar with more cold tolerance and higher yields, has produced 27 to $77 \%$ greater steer gains than Gulf annual ryegrass in Alabama grazing trials (Bransby et al. 1997). 'Dixie', the first naturally reseeding crimson clover, was released in 1946 and has remained the dominant cultivar (Hoveland and Evers 1995). 'Yuchi' arrowleaf clover, released in the mid 1960 s, had a longer productive season and less bloat potential than crimson so by 1992 it was the most widely grown winter annual clover (Hoveland and Evers 1995). Since then, disease problems have reduced the hectarage of this clover. 
Near infrared reflectance spectroscopy for forage quality analysis

Hay and silage analysis for nutritive quality is necessary in feeding to meet nutrient needs of animals. Unfortunately, chemical procedures for quality evaluation are slow and expensive. Near infrared reflectance spectroscopy for forage quality analysis, first used in 1976, has been rapidly adopted by laboratories because it is accurate, rapid, repeatable, and inexpensive (Norris et al. 1976). It has given livestock producers useful information in feeding, a better appreciation of forage quality, and encouraged better forage management. As a result, more hay is being bought and sold on the basis of forage analysis rather than on color, smell, or leafiness.

\section{Future Areas of Emphasis in Grassland Improvement}

Predicting the future is always risky because a single innovation, research breakthrough, political decision, consumer attitude change, or economic shift may alter the production and market arenas. Science is unpredictable and one can never say where a given field of research will lead (Jacob 1998). This is complicated by the interrelationships of world trade, political instability of many countries, and pressures of growing populations on land and other resources. It is likely that humid grasslands will shrink in area with more urbanization and pressure for cropping on the best soils. Thus, it is likely that future humid grasslands will increasingly be located on less desirable sites with greater environmental stresses on forage plants. Pasture cultivars of the future must be able to tolerate the stresses of poor soils, grazing, and possibly more heat and drought if global warming becomes a reality. In this context, some future areas of emphasis on grassland improvement and use are considered.

\section{Greater use of grazing-tolerant grass- es and legumes}

Most perennial cool season grass and legume cultivars in the USA have not been selected under grazing for pasture use (Bouton et al. 1997). These cultivars perform well when harvested as hay or silage but often do not persist under close continuous grazing common on beef cattle farms. The most successful pasture grasses have been those selected from old pastures such as Kentucky 31 tall fescue. Future pasture grass and legume cultivars will be selected under close grazing by livestock so they are tolerant of frequent close defoliation and hoof treading. Total forage yield of grass and legume cultivars will be of less importance than dependability and persistence under grazing in competition with other species.

Stress-tolerant tall fescue with "friend$l y "$ non-toxic endophytes

The fungal endophyte Neotyphodium coenophialum is best known for its toxic effects on livestock consuming the forage but there is also a mutualistic relationship which benefits the host plant, in this case tall fescue. The most important benefit appears to be drought tolerance by several means such as faster and deeper root development, higher stomatal resistance, lower net photosynthetic rate, enhanced osmotic adjustment in the meristematic and growing zone, and better maintenance of water content in the growing zone (Latch 1997). Other benefits appear to be increased herbage production and plant tillering, more efficient utilization of $\mathrm{N}$, improved seed production, and improved resistance to several diseases and nematodes.

The discovery of non-toxic endophytes has opened exciting opportunities for the future that have the potential to overcome the serious livestock losses with tall fescue. These non-toxic endophytes can be inserted into endophyte-free tall fescue and furnish excellent animal performance while the host plant appears to have benefits similar to plants containing toxin-producing endophytes (Latch 1997). Pastures planted with tall fescue containing a "friendly" endophyte will be non-toxic but be as persistent under grazing as infected toxic tall fescue. In addition to benefitting traditional tall fescue production areas, this development should allow expansion of non-toxic tall fescue planting into stressful environments where endophytefree cultivars do not persist.

\section{Antidotes to the toxins of endophyte- infected tall fescue}

Immunization of animals against various disease organisms is a common practice. A similar system for fescue toxicity would be an effective way to protect animals from the syndrome while utilizing low-cost existing endophyte-infected tall fescue pastures. Research in progress suggests that this approach has promise. Immunization would involve direct introduction of a generated immunogen or antigen against which the recipient animal produces antibodies which protect against the toxins (Larson 1997). To be successful, it will be necessary in stimulating the intestinal immune system to secrete antibodies at rumen and intestinal surfaces in sufficient quantity to neutralize ingested toxins if the antibody/antigen complex is not degraded. Another approach with promise is treatment of animals with domperidone when grazing toxic tall fescue. This D2 dopamine receptor antagonist has been effective in alleviating toxicity symptoms in cattle (Campbell et al. 1999) and gravid mares (Dooley et al. 1999).

\section{Use of herbicide-and pest-resistant genes in forage plants}

Molecular approaches for weed, insect, and disease problems by transforming or inserting new DNA in plant cells have been successful in crop plants (Wilkinson 1997). 'Roundup ready' cotton and soybeans give the crop plant resistance to the herbicide while weeds are killed. Genes for insect resistance have been introduced into crops such as corn, cotton, and potato. Efforts to accomplish this have been concentrated on crop plants as the market potential is larger. However, it is expected that 'Roundup ready' alfalfa should be on the market within 3 years and other forages will probably follow. Forage establishment, often a difficult period, would be much more dependable with excellent weed control from this new technology. Greater insect resistance would reduce the need for insecticides to control alfalfa weevil, leaf hoppers, and other insects.

\section{Use of gypsum to alleviate subsoil acidity}

Many soils, particularly in the lower South, have very acid subsoils which inhibit root growth because of aluminum toxicity at $\mathrm{pH}$ levels below 5.2. Thus, the root zone is restricted to a shallow layer having a favorable soil $\mathrm{pH}$ and many forage plants cannot utilize water deeper in the soil. Even short periods of drought result in water stress to forage legumes such as alfalfa. Putting limestone deep into the soil is expensive. In contrast, gypsum (calcium sulfate) mixed into the soil surface will after a year move into the subsoil, inactivating the toxic aluminum, supplying calcium, and allowing roots to grow deeper in the soil to obtain water for continued growth during dry periods (Sumner et al. 1986). The effects of one gypsum application will benefit yields for 10 to 15 years. Gypsum application on many soils will allow successful production of alfalfa for pasture or stored feed on many soils where it was not well adapted. 
Greater use of computers in information access and decision making

Reduction in funding for extension personnel will probably continue in the future. Forage information will increasingly be available on computer networks. The opportunity for access to research information on the internet will allow rapid utilization of new findings. In addition, more software programs will be available to assist forage and livestock producers in making decisions based on expected cost/benefit.

\section{Greater use of forages for wildlife food}

More forages will continue to be planted to attract deer, wild turkey, quail, and other wildlife. In addition to existing hunting preserves in many areas of the South, many cattle producers will be encouraging wildlife with special plantings to attract wildlife for hunters and also urban families wishing to enjoy nature. Many of these livestock producers will also rent cottages or efficiency apartments for guests on their farms.

\section{Breeding of pasture plants with greater winter productivity}

Many of the widely grown perennial cool season grass and legume cultivars have considerable winter dormancy which is useful in the north for cold hardiness but in the lower South winter productivity would be an advantage. 'AU Triumph' was the first tall fescue cultivar with substantially more winter production, furnishing generally 6 weeks more grazing than Kentucky 31 and similar cultivars (Hoveland et al. 1982). Unfortunately, the lower environmental stress tolerance of this first endophyte-free cultivar along with a more erect growth habit made it less persistent under close continuous grazing so it fell into disfavor by livestock producers. However, greater breeding efforts for cool season productivity using stress-tolerant germplasm in the future should result in cultivars that furnish more winter grazing, thereby reducing hay requirements.

\section{Development of a perennial grass bio- mass energy industry}

The USA imports one-half of its petroleum requirements and this is expected to increase as domestic reserves of oil decline. Research has been active in developing renewable energy sources from plant biomass, resulting in viable processing methods for production of ethanol or methanol (McLaughlin et al. 1996). Biomass is also a useful component in generation of electric power. Switchgrass is one of the most productive perennial grasses for these purposes and yields are higher in the southern USA than in other parts of the country (Bransby et al. 1993). Also, this grass can be grown on poor land not suited to crops, soil is protected from erosion, wildlife are encouraged, and harvesting can be mechanized. Increasing dependence on import of petroleum seriously affects our national balance of payments deficit. The cost of imported oil could be vastly reduced and rural communities benefitted by development of processing plants and production of grass biomass to create jobs and income.

\section{Conclusions}

Southern grasslands, developed from former row crop land since the 1930's, consist mainly of tall fescue, bermudagrass, and bahiagrass pastures utilized for beef cow-calf production. Legumes are an important component of pastures in the upper South but are generally undependable and often absent in the stressful environment of the lower South. Research accomplishments have had a major impact on grassland development in the South.

In addition to the lower input beef cowcalf industry, grazing of stocker steers from weaning to feeder weight on intensively managed winter annual pastures has been increasing. With consolidation of the beef finishing and processing industries, it is likely that contract grazing will increase on high-quality annual and perennial pastures. With greater emphasis on higher quality pastures and management, there will be a continuing need for innovative research on utilization of Southern grasslands.

\section{Literature Cited}

Anonymous. 1998. Cattle inventory. Nat. Agr. Statist. Serv. USDA. Washington, D.C.

Bacon, C.W., J.K. Porter, J.D. Robbins, and E.S. Luttrell. 1977. Epichloe typhina from toxic tall fescue grasses. Appl. Environ. Microbiol. 34:521-581.

Ball, D.M., C.S. Hoveland, and G.D. Lacefield. 1996. Southern Forages. PPI and FAR, Norcross, Ga.

Blaser, R.E., D.D. Wolf, and H.T. Bryant. 1973. Systems of grazing management. $p$. 581-595. In: M.E. Heath, D.S. Metcalfe, and R.T. Barnes. Forages, the science of grassland agriculture. Third edition. Iowa State Univ. Press, Ames, Iowa

Bouton, J.H., C.S. Hoveland, and R.N. Gates. 1997. Use of the grazing animal in forage breeding. p. 4-7. ID 174. Proc. 18th Int. Grassl. Congr., Winnipeg, Manitoba, Canada.

Bouton, J.H., S.R. Smith, Jr., D.T. Wood, C.S. Hoveland, and E.C. Brummer. 1991. Registration of 'Alfagraze' alfalfa. Crop Sci. 31:479.

Bransby, D.I., M. Pegues, and R. Rawls. 1997. Marshall ryegrass drastically superior under grazing. Alabama Highlights of Agr. Res. 44, No. 2. p. 12-14.

Bransby, D.I., R. Rodriguez-Kabana, and S.E. Sladden. 1993. Compatibility of switchgrass as an energy crop in farming systems of the southeastern USA. p. 229-234. Proc. 1st Biomass Conf. of the Americas: energy, environment, agriculture, and industry. 30 Aug-2 Sept, 1993, Burlington, Vt. National Renewable Energy Laboratory, Golden, Colo.

Buckner, R.C., J.B.Powell, and R.V. Frakes. 1979. Historical development. In: L.P. Bush (ed.) Tall fescue. Agronomy 20:1-8. Amer. Soc. Agron., Madison, Wisc.

Burson, B.L. and V.H. Watson. 1995. Bahiagrass, dallisgrass, and other Paspalum species. p. 431-440. In: R.F. Barnes, D.A. Miller, and C.J. Nelson. Forages Vol. I: An introduction to grassland agriculture. Iowa State Univ. Press. Ames, Iowa.

Burton, G.W. 1954. Coastal bermudagrass. Georgia Agric. Exp. Stn. Bull. NS 2.

Burton, G.W. 1989. Registration of Tifton 9 bahiagrass. Crop Sci. 29:1326.

Burton, G.W. and W.W. Hanna. 1995. Bermudagrass. p. 421-429. In: R.F. Barnes, D.A. Miller, and C.J. Nelson. Forages. Vol. I: An introduction to grassland agriculture. Iowa State Univ. Press. Ames, Iowa.

Campbell, C.E., D.L. Cross, J.W. Irwin, W.C. Bridges, and C.E. Thompson. 1999. The effect of a D2 dopamine receptor antagonist on fescue toxicosis in beef cattle. Abstr. Amer. Soc. Anim. Sci. Southern Br. 30 Jan-2 Feb, 1999. Memphis, Tenn. p. 8-9.

Dooley, K.M., D.L. Cross, and T. Gimenez. 1999. Effect of dosing length and endophyte presence on reproduction in gravid mares treated with a D2 dopamine receptor antagonist. Abstr. Amer. Soc. Anim. Sci. Southern Br. 30 Jan-2 Feb, 1999. Memphis, Tenn. p. 18.

Fergus, E.N. 1952. Kentucky 31 fescue - culture and use. Kentucky Agr. Ext. Cir. 497.

Finlayson, E.H. 1941. Pensacola, a new fineleafed bahia. Southern Seedsman 4:9-28.

Hoveland, C.S. 1992. Grazing systems for humid regions. J. Prod. Agr. 5:23-27.

Hoveland, C.S. 1993. Importance and economic significance of the Acremonium endophytes to performance of animals and grass plant. p. 3-12. In: R. Joost and S. Quisenberry (ed.) Acremonium/grass interactions. Elsevier, Amsterdam.

Hoveland, C.S. and G.W. Evers. 1995. Arrowleaf, crimson, and other annual clovers. p. 249-260. In: R.F. Barnes, D.A. Miller, and C.J. Nelson. Forages. Vol. I: An introduction to grassland agriculture. Iowa State Univ. Press. Ames, Iowa. 
Hoveland, C.S., R.L. Haaland, C.D. Berry, J.F. Pedersen, S.P. Schmidt, and R.R. Harris. 1982. Triumph - a new winter productive tall fescue variety. Alabama Agr. Exp. Sta. Cir. 260

Hoveland, C.S., S.P. Schmidt, C.C. King, J.W. Odum, E.M. Clark, L.A. Smith, H.W. Grimes, and J.L. Holliman. 1983. Steer performance and Acremonium coenophialum fungal endophyte on tall fescue pasture. Agron. J. 75:821-824.

Jacob, F. 1998. Of flies, mice, and men. Harvard Univ. Press, Cambridge, Mass.

Larson, B. 1997. Neotyphodium toxicosis: an animal cellular/molecular research technique perspective. p. 347-360. In: C.W. Bacon and N.S. Hill (ed.) Neotyphodium/grass interactions. Plenum Press, NY.

Latch, G.C.M. 1997. An overview of Neotyphodium-grass interactions. p.1-11. In: C.W. Bacon and N.S. Hill (ed.) Neotyphodium/grass interactions. Plenum Press, N.Y.
Mott, G.O. 1960. Grazing pressure and the measurement of pasture production. p.606-611. In: Proc. 8th Int. Grassl. Congr., 11-21 July 1960. British Grassl. Soc., Hurley, Berkshire, England.

McLaughlin, S.B., R. Samson, D. Bransby, and A. Wiselogel. 1996. Evaluating physical, chemical, and energetic properties of perennial grasses as biofuels. Bioenergy '96. Vol. I. p. 1-7. Proc. 7th national bioenergy conference. Nashville, Tenn. 15-20 Sept. 1996.

Norris, K.H., R.F. Barnes, J.E. Moore, and J.S. Schenk. 1976. Predicting forage quality by infrared reflectance spectroscopy. J. Anim. Sci 43:889.

Rotz, C.A., and R.E. Muck. 1994. Changes in forage quality during harvest and storage. $\mathrm{p}$. 828-868. In: Forage quality, evaluation, and utilization. ASA, CSSA, and SSA. Madison, Wisc.

Rotz, C.A. and H.A. Muhtar. 1991. Rotary power requirements for agricultural equipment. Paper 911550. Amer. Soc. Agr. Engr., St. Joseph, Mich.
Sumner, M.E., H. Shahandah, J. Bouton, and J. Hammel. 1986. Amelioration of an acid soil profile through deep liming and surface application of gypsum. Soil Sci. Soc. Amer. J. 50:1254-1258.

Weihing, R.M. 1963. Growth of ryegrass as influenced by temperature and solar radiation. Agron. J. 55:519-521.

Wilkinson, J.Q. 1997. Biotech plants: from lab bench to supermarket shelf. Food Tech. Vol. 51. No. 12. p. 37-42.

Wilkinson, S.R. and G.W. Langdale. 1974. Fertility needs of the warm season grasses. $p$. 119-145. In: D.A. Mays (ed) Forage fertilization. ASA, CSSA, and SSSA, Madison, Wisc.

Statement of Ownership, Management, and Circulation

(Act. of August 12, 1970, Sec. 3685, Title 39, United States Code)

1. Title of Publication: Journal of Range Management

2. Date of Filing: September 9, 1999

3. Frequency of Issue: Bimonthly

4. Location of Office of Publication: 445 Union Blvd., Suite 230, Lakewood, Colorado 80228

5. Location of General Business Office: Same

6. Name and Address of:

Publisher: Society for Range Management, 445 Union Blvd., Suite 230, Lakewood, Colorado 80228

Editor: Gary Frasier, 7820 Stag Hollow Road, Loveland, Colo. 80538

Managing Editor: J. Craig Whitekiend, 445 Union Blvd., Suite 230, Lakewood, Colorado 80228

7. Owner: Society for Range Management, 445 Union Blvd., Suite 230, Lakewood, Colorado 80228

8. Known Bondholders, Mortgages, etc.: Membership

9. For Completion by Nonprofit Organizations Authorized to Mail at Special Rates: The purpose, function, and nonprofit status of this organization and the exempt status for Federal income tax purposes have not changed during preceding 12 months.

10. Extent and Nature of Circulation

A. Total copies printed

B. Paid Circulation

1. Dealers, counter sales

2. Mail subscriptions

C. Total paid circulation

D. Free distribution

E. Total distribution

F. Copies not distributed

G. Total

$\begin{array}{cc}\begin{array}{c}\text { Avg. for } \\ 12 \text { months } \\ 2,779\end{array} & \begin{array}{c}\text { Actual for } \\ \text { issue nearest } \\ \text { filing date } \\ 2,668\end{array} \\ 0 & \\ 2,447 & 0 \\ 2,447 & 2,390 \\ 15 & 2,390 \\ 2,462 & 15 \\ 317 & 2,405 \\ 2,779 & 263 \\ & 2,668\end{array}$

I certify that the statements made by me above are correct and complete $-J$. Craig Whitekiend, Managing Editor. 